\title{
Expanding the contribution of community gardens to city sustainability through family education programs.
}

STAVRIANAKIS, K. and FARMER, J.

2019

(C) CYE Network. Originally published on JSTOR: https://doi.org/10.7721/chilyoutenvi.29.1.0084. Use of this file is subject to the JSTOR terms of use: https://about.jstor.org/terms 


\section{Expanding the Contribution of Community Gardens to City Sustainability through} Family Education Programs

\section{Author(s): Konstantinos Stavrianakis and James Farmer}

Source: Children, Youth and Environments, Vol. 29, No. 1 (2019), pp. 84-104

Published by: University of Cincinnati

Stable URL: https://www.jstor.org/stable/10.7721/chilyoutenvi.29.1.0084

JSTOR is a not-for-profit service that helps scholars, researchers, and students discover, use, and build upon a wide range of content in a trusted digital archive. We use information technology and tools to increase productivity and facilitate new forms of scholarship. For more information about JSTOR, please contact support@jstor.org.

Your use of the JSTOR archive indicates your acceptance of the Terms \& Conditions of Use, available at https://about.jstor.org/terms 


\title{
Expanding the Contribution of Community Gardens to City Sustainability through Family Education Programs
}

\author{
Konstantinos Stavrianakis \\ James Farmer \\ School of Public Health, Indiana University, Bloomington
}

\begin{abstract}
Citation: Stavrianakis, K., \& Farmer, J. (2019). Expanding the contribution of community gardens to city sustainability through family education programs. Children, Youth and Environments, 29(1), 84-104. Retrieved from

http://www.jstor.org/action/showPublication?journalCode=chilyoutenvi
\end{abstract}

\begin{abstract}
Limited outdoor residential spaces and the cost of high-quality, sustainably grown vegetables have led families to engage in community gardening. The educational and recreational opportunities provided by community gardening make the settings an appealing location for families to learn and share leisure time together. We used a mixed-methods approach to investigate the impacts that gardening education workshops in community gardens can have on family members and their environmental behaviors. We used a case study approach to analyze the data from observations, drawings and interviews in which participants reported a variety of positive impacts from the gardening workshops including socializing, health benefits and acquired knowledge. However, there was limited evidence of pro-environmental behavior change beyond gardening.
\end{abstract}

Keywords: community gardens, families, sustainability, mixed methods, education 


\section{Introduction}

Community gardens have been utilized in different periods of history by individuals to produce fresh fruits during a crisis (Okvat \& Zautra, 2011; Robinson \& Farmer, 2017). Such gardens were used during the Great Depression, and they were a great relief during and after World War I and II (Armstrong, 2000; Lawson, 2005). Guitart, Pickering, and Byrne (2012) suggest that there has been a global increase in urban community gardens, signifying their importance to modern societies, which was also underscored by Turner, Henryks, and Pearson (2011).

There are a variety of community garden types and systems. Veen and colleagues (2015) differentiate between allotments in community gardens managed by multiple people through collective action, and allotments managed by individuals or family-style units. Additionally, Ferris, Norman, and Sempik (2001) distinguish community gardens based on function, such as food gardens, leisure gardens, healing and therapy gardens, and crime diversion gardens.

The continuous increase of vegetable prices, the scarcity of vegetables, and the poor quality of commercially available vegetables, particularly in food-insecure regions, have been found to be some of the reasons that lead individuals to engage in community gardening (Hendrickson, Smith, \& Eikenberry, 2006). There are inconclusive studies suggesting that food habit changes towards a vegetable-rich diet with less meat and dairy consumption could result in a more environmentally sustainable lifestyle (Macdiarmid, 2013). While eating healthy and sustainable foods is possible, Barosh, Friel, Engelhardt, and Chan (2014) point out that for households with certain socioeconomic characteristics, adopting such a diet may be unaffordable. Community gardening can be a solution to that problem by providing individuals with access to a more sustainable-and affordable-diet (Algert, Baameur, \& Renvall, 2014; Turner, 2011).

Our study used the Brundtland Report's description of sustainability: "sustainability is concerned with the well-being of future generations and in particular with irreplaceable natural resources." Further, this paper uses the definition of proenvironmental behavior by Kollmuss and Agyeman (2002) as "the behavior that consciously seeks to minimize the negative impact of one's actions on the natural and built world" (p. 240), such as limiting the usage of plastic bags.

Turner (2011) discusses how communities can come together through food systems by engaging in community gardening. Furthermore, scholars have posited that community gardens promote sustainability, environmental stewardship, and education (Krasny \& Tidball, 2009), as well as offer a range of ecosystem services such as biodiversity and decomposition (Ferris et al., 2001; Middle et al., 2014). Okvat and Zautra (2011) include in their study two ways that gardening can specifically mitigate climate change; the first is through direct impacts, such as mitigation of greenhouse gasses, and the second is via indirect impacts such as "urban lifestyle change and education" (p. 380).

The aim of our research is to investigate whether educational gardening workshops offered in community gardens can bolster pro-environmental behaviors among 
family members and promote sustainable ways of living. Our hypothesis is that the educational workshops will have a positive impact on the family members participating in them.

Many studies that have investigated the educational role of community gardens have focused on the individual and her/his experiences rather than the family unit and how they experience and learn together (Corkery, 2015; Walter, 2013). Recently, research has centered on the cognitive development of the individuals involved in community garden projects, with little attention directed towards families and their conceptual change regarding issues of sustainability. The importance of the family unit is underscored by MacDonald and Maurer (2015) who proposed that family knowledge acquisition can be achieved in an informal setting while engaging in enjoyable activities together. Damerell, Howe, and Milner-Gulland (2013) suggested that parents can learn from their children while they are engaged together in environmental education activities, but they suggest that further empirical evidence is needed on the matter.

A critical gap in scholarship centers on the family and the factors contributing to the family unit's experience, their attitude towards sustainability and how their behaviors change while engaging in community gardens. Scholars propose that the family unit is the most important social structure for children, with respect to behavioral and attitude changes (Patterson, 1975). Several studies have commented on the influence that parents have on their children. For example, (Lauricella, Wartella, \& Rideout, 2015), reported that children's screen time was associated with their parents' screen time; Meeusen (2014) suggested that parents have a significant impact on the environmental concerns of their child. As children are the adults of the future who will be making conscious decisions, it is important to understand the best ways to educate them and raise their environmental awareness. Family interventions may be a way to achieve that, however we must first understand how families function and behave, how the members of families interact, and the different ways they socialize.

Recent literature indicates that more empirical research in community gardening is needed in order to further explore family sustainability. For example, Guitart et al. (2012), examined 89 community garden research publications and found that environmental sustainability was discussed in 19 of the papers but demonstrated in only two. Multiple studies investigated the role of families and community gardens from a health perspective (e.g. vegetable intake and obesity) (Carney et al., 2012; Castro, Samuels, \& Harman, 2013; Zick, Smith, Kowaleski-Jones, Uno, \& Merrill, 2013), but the sustainability aspect of community gardens tends to be addressed more in school environments (Williams \& Brown, 2013). Consequently, the present study investigated individual plots managed by families in community gardens.

\section{Methods}

\section{Study Location}

The community garden investigated in our study is part of Hilltop Garden and Nature Center (Hilltop) on the Indiana University-Bloomington campus, in the 
midwestern U.S. Bloomington is a city in south-central Indiana with a population of 83,093 people ("US Towns in Profile," n.d.). It is a college town with 32,924 undergraduate students and 10,289 graduate students ("Indiana University," 2016). The average household income in 2016 was $\$ 31,254$ and $56.5 \%$ of the people above 25 years of age had a bachelor's degree or a higher qualification (United States Census Bureau, 2017). In addition to Hilltop, there are four more community gardens in the town that are open to the public. We chose the study location because the agency offers family educational workshops and participants included both members of the public with no affiliation to the university, as well as employees/students of the university. Hilltop was established in 1948 with a focus on youth gardening.

Through the years, Hilltop's educational programs have evolved and they now offer workshops for children, adults, and families. Their education program is not curriculum-based and the teaching methods and objectives change based on the instructor. ${ }^{1}$ There are specific topics that community gardeners learn every season, such as soil quality, pest identification, water conservation, weeding and mulching. Instructors embed experiential, interactive activities into their educational workshops. Children's activities include coloring with leaves and flowers, building birdhouses, insect observation under the microscope, and the like. The content of the workshops does not explicitly include sustainability nor the role that community gardens may play; rather, workshops focus on organic vegetable and fruit growing practices. Although the vegetable gardens in the nature center do not have an organic produce certification, the practices they follow and teach in gardening are in accordance with organic agriculture practices. In addition to the educational programs and the instructors, the nature center also provides the gardeners with all the gardening supplies they need such as compost, seeds, and gardening tools.

\section{Approach ${ }^{2}$}

We used a sequentially embedded mixed-methods study to allow for one phase to inform proceeding phases (Creswell \& Plano-Clark, 2007). We followed a case study approach, utilizing both qualitative and quantitative analytical methods (Stake, 2005).Data were collected in three different phases with three different methods between May 2017 and September 2017. We started by conducting family observations and transitioned to interviews with the older family members and drawings completed with the younger family members. This allowed us to study the phenomenon of family community gardening from multiple lenses, gaining greater depth and understanding of the lived experience (Creswell, 2013). Thirteen total families were involved in the study, which included 39 individual participants. The families had diverse experience with and knowledge about community gardening. Participation in this study was voluntary and each family received a $\$ 50$ gift card incentive to participate. We collected quantitative data through ethogram observations that were later quantified, while the qualitative data were collected via informal, in-depth interviews and drawings. For the purpose of the observations, we

\footnotetext{
1 The researchers did not contribute to any educational material or instruction.

2 The Independent Research Board at Indiana University, Bloomington, approved the study (IRB \#1709177902).
} 
constructed an ethogram according to Bernard (2006) and Nippert-Eng (2015); its development is explained below. Our interview protocol was open-ended for the purposes of the informal interviews that elicited the experiences and perceptions of both adults and children during their participation in the community gardening (Tracy, 2012). The drawings included the experiences and perceptions of the younger participants during their engagement in gardening, as per Hsu (2014). We also collected demographic data about the participants.

To analyze the data, we followed characteristic procedures of a case study method, including naturalistic generalizations, direct interpretation, categorical aggregation and correspondence and patterns (Stake, 1995). For the analysis of our data we focused on individual experiences and what individuals made of the education workshops, as well as the aggregation of individual meanings in order to understand the larger relationship between Hilltop Nature and Garden center and the participants. For that reason we analyzed our data both through the aggregation of cases and individuals' direct interpretation (Stake, 1995).

\section{Observations}

Stage 1 of the data collection was the family observations. The observation process was based on an ethogram we developed during two pilot visits in the community gardens where we identified the main behaviors in which we were interested (see an example ethogram in Appendix A). The main reason for using an ethogram was to be able to compare behaviors among family members to see whether there were any correlations or differences among them. The four main themes of the codebook were: 1) Environmental Knowledge (five behaviors), 2) Emotions (four behaviors), 3) Engagement (five behaviors), and 4) Environmental Behavior (12 behaviors). The individual behaviors that were coded for these four themes can be found in Appendix $B$. The duration of the observations varied between 20 and 45 minutes with an average duration of 41.4 minutes. In total, we completed 39 observations of the 13 different families. The family observations took place one at a time, ensuring that the observer captured most of the behaviors developing in the observed period. The total number of observations varied between families. In addition to the behaviors, we also recorded: a) the subject of the education workshop, b) the weather conditions, and c) the time and date of the observation.

Once all observations were complete $(n=39)$, each individual observation theme was given a separate score, one for the parents' behaviors and one for the children's behaviors. Scoring the observations was important for making our data continuous and appropriate for the statistical analysis. We used knowledge and engagement as our predictor variables for environmental behavior. We used Spearman's rank correlation coefficient to determine the relations between parents' and children's environmental behavior scores with engagement and knowledge scores; $\mathrm{p}<0.05$ was considered statistically significant.

\section{Drawings}

Stage 2 of the data collection was the children's drawings. Although drawing is not a methodology widely used in research, it is becoming more popular with research involving children (Tracy \& Redden, 2016). Drawings are used by children to 
represent what they learn in their daily life through memories, events and realworld observations (Hsu, 2014). In her paper, (Yuen, 2004) discussed four contexts where drawing can be helpful: "a) to facilitate a relaxed atmosphere, b) to gain insight into the children's perspective, $c$ ) to provide structure and focus the discussion, and d) to recognize and reduce the potential of group-think" (p. 461). In this study, the children produced their drawing at their house and returned it to us at the community garden. The prompt for the drawing was, "Please draw your experience from the community gardens. You can include plants, animals, people and anything else you want."

We used an adapted version of the draw-and-explain method used by Günindi (2017); our participants verbally explained their drawings during the interviews, rather than writing their explanations. Discussing the drawings with the children and their parents while we interviewed them together served as a triangulation method (Copeland \& Agosto, 2012). Further, recognizing the young ages of some of the participants, this approach allowed them to better express their experiences, and helped guide the discussion according to what the children had experienced and wanted to share with the family and the researcher.

\section{Informal Interviews}

Stage 3 of the data collection was the on-site informal, in-depth interviews conducted with the families. The main purpose of the interviews was to find emerging themes on the experiences and motivations that led families to engage in the community garden programs and the educational workshops. Not all 13 families participated in the interview process. In total, we conducted seven individual family interviews $(n=7)$. All family members that participated in the educational workshops were present during the interviews, which took place at the community garden. The duration of the interviews was between 14 minutes and 19 minutes with an average duration of 17 minutes. We followed a focus group openended interview protocol, as we were interested in family interactions and experience sharing (Tracy, 2012). The interview questions focused on three main themes that emerged throughout the observations:

1) The positive or negative impacts that the community garden had on the family;

2) The reasons for participating in the specific community garden and if they would continue engaging in community gardens; and

3) The experience of the children participating with their family in community gardening.

\section{Results}

Our study participants included 39 (14 male (36\%) and 25 female (64\%)) parents $(n=39)$ and their children $(n=14)$ engaging in community gardening. The mean age for parents was 34.75 with the majority being full-time employees and holders of at least a bachelor's degree. The average number of children in the participating families was 1.5 , and $73.5 \%$ of the child participants were girls. 


\section{Observations}

Correlation analysis of the observations suggests children's environmental behavior was significantly correlated with their parents' engagement $(P<0.001)$, and their family combined engagement ${ }^{3}(P<0.041)$ (Table 1$)$. Table 2 , in contrast, shows that parents' environmental behavior was not found to be correlated with their children's engagement, but it was correlated with parents' engagement $(P<0.023)$. Combined family environmental behavior was significantly correlated with parents' engagement $(P<0.000)$, family combined engagement $(P<0.027)$, parents' environmental behavior $(P<0.000)$, and children's environmental behavior $(P<0.000)$ (Table 3$)$. We did not find any significant correlations between environmental behavior and environmental knowledge, neither for parents nor for children.

\section{Table 1. Spearman's rank correlation between children's environmental} behavior and engagement

\begin{tabular}{|r|l|l|}
\hline $\begin{array}{r}\text { Children's environmental } \\
\text { behavior }\end{array}$ & $\begin{array}{l}\text { Parents' } \\
\text { engagement }\end{array}$ & $\begin{array}{l}\text { Family } \\
\text { engagement }\end{array}$ \\
\hline Correlation coefficient & $.504^{* *}$ & $.329^{*}$ \\
\hline Sig. (2 tailed) & 0.001 & 0.041 \\
\hline $\mathrm{N}$ & 39 & 39 \\
\hline$* *$ Correlation is significant at the 0.01 level (2-tailed) \\
\hline$*$. Correlation is significant at the 0.05 level (2-tailed) \\
\hline
\end{tabular}

Table 2. Spearman's rank correlation between parents' environmental behavior, parents' engagement and combined family environmental behavior

\begin{tabular}{|r|l|l|}
\hline $\begin{array}{l}\text { Parents' environmental } \\
\text { behavior }\end{array}$ & $\begin{array}{l}\text { Parents' } \\
\text { engagement }\end{array}$ & $\begin{array}{l}\text { Family environmental } \\
\text { behavior }\end{array}$ \\
\hline Correlation coefficient & $.364^{*}$ & $.766^{* *}$ \\
\hline Sig. (2 tailed) & 0.023 & 0.000 \\
\hline $\mathrm{N}$ & 39 & 39 \\
\hline$* *$ Correlation is significant at the 0.01 level (2-tailed) \\
\hline$*$. Correlation is significant at the 0.05 level (2-tailed) \\
\hline
\end{tabular}

\footnotetext{
${ }^{3}$ Engagement refers to specific actions as found in the ethogram's codebook in Appendix B
} 
Table 3. Spearman's rank correlation between families' environmental behavior, engagement and parents' and children environmental behavior

\begin{tabular}{|l|l|l|l|l|}
\hline $\begin{array}{l}\text { Families' } \\
\text { environmental } \\
\text { behavior }\end{array}$ & $\begin{array}{l}\text { Parents' } \\
\text { engagement }\end{array}$ & $\begin{array}{l}\text { Combined } \\
\text { engagement }\end{array}$ & $\begin{array}{l}\text { Parents' } \\
\text { environmental } \\
\text { behavior }\end{array}$ & $\begin{array}{l}\text { Children's } \\
\text { environmental } \\
\text { behavior }\end{array}$ \\
\hline Correlation coefficient & $.625^{* *}$ & $.354^{*}$ & $.766^{* *}$ & $.713^{* *}$ \\
\hline Sig. (2 tailed) & 0.000 & 0.027 & 0.000 & 0.000 \\
\hline $\mathrm{N}$ & 39 & 39 & 39 & 39 \\
\hline$* *$ Correlation is significant at the 0.01 level (2-tailed) \\
\hline *. Correlation is significant at the 0.05 level (2-tailed)
\end{tabular}

\section{Drawings}

In total, we found 29 codes and six themes from analyzing the children's drawings (Table 4). The majority of the drawings included people such as themselves and their family members; plants such as tomatoes, apple trees, and potatoes; and animals such as the resident cat, rolly-pollys (pill bugs), worms, and birds. An example of the drawings with a brief description can be seen in Figures 1, 2 and 3 .

Table 4. Themes and codes derived from analyzing the drawings

\begin{tabular}{|c|c|c|}
\hline Themes & \multicolumn{2}{|c|}{ Codes } \\
\hline Knowledge & $\begin{array}{l}\text { Blue carrot } \\
\text { Watering }\end{array}$ & Sun \\
\hline Emotions & Love & \\
\hline Family & $\begin{array}{l}\text { Father } \\
\text { Mother }\end{array}$ & $\begin{array}{l}\text { Brother } \\
\text { Me }\end{array}$ \\
\hline Produce/plants & $\begin{array}{l}\text { Tomatoes } \\
\text { Lettuce } \\
\text { Potato } \\
\text { Kale }\end{array}$ & $\begin{array}{l}\text { Pepper } \\
\text { Apple tree } \\
\text { Peer tree } \\
\text { Blueberry bush }\end{array}$ \\
\hline Animals & $\begin{array}{l}\text { Cat } \\
\text { Bird } \\
\text { Worm }\end{array}$ & $\begin{array}{l}\text { Rolly polly } \\
\text { Bunny }\end{array}$ \\
\hline Infrastructure & $\begin{array}{l}\text { Classroom } \\
\text { Tool } \\
\text { Fence } \\
\text { Plot }\end{array}$ & $\begin{array}{l}\text { Bucket } \\
\text { Shovel } \\
\text { Wheelbarrow }\end{array}$ \\
\hline
\end{tabular}




\section{Emotions and Knowledge}

Figure 1. Drawing capturing emotions and knowledge

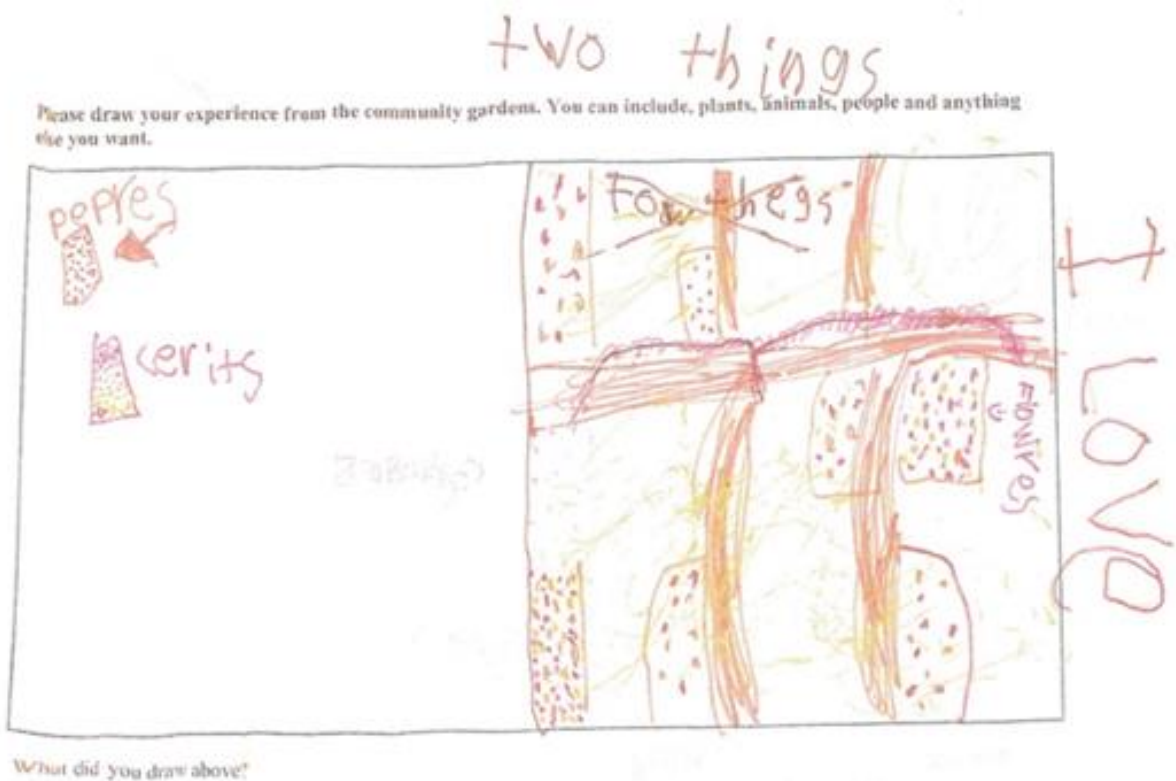

A 6-year-old girl created the drawing in Figure 1. Based on the illustration, we can see that the child loves peppers and carrots. The interview with the child and the parent allowed us to get a more in-depth understanding of the drawing and the child's experience in community gardening. The child pointed out that carrots are not necessarily orange, but can be blue as well. The child also said that she drew tomatoes, and she loved gardening because she can grow food and eat it.

\section{Garden Production}

\section{Figure 2. Garden produce and gardening tools} Please draw your experience from the community gardens. You ean include, plants, animals, people and anything
else you want.

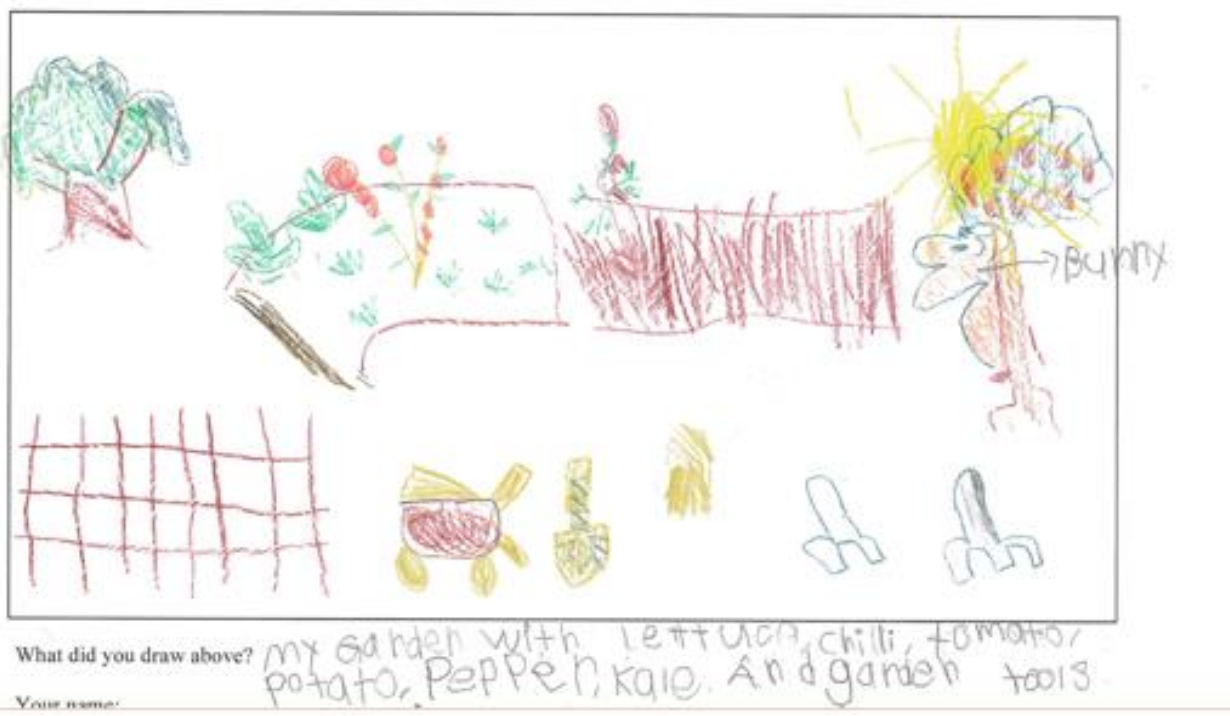


Figure 2 is a 6-year's old boy's drawing illustrating his experiences in community gardening. From the drawing, we can see that the child has drawn different types of plants. The shapes of the plants drawn are relatively realistic and can be defined in the picture. In the interview, he explained that he drew weeds and that he did not like weeds. In the drawing, both large trees and small plants had fruit. He also drew several different types of gardening tools and seem to know the function of at least one, the watering can, by representing water. He drew a fence, but it was not clear what the function of the fence was in either the interview or the drawing. He also drew a rabbit and explained that the rabbit was stealing the apples. From this data, we can infer that the child knows that different plants produce different types of food, that different types of tools are needed to tend the garden, and that he possibly understands some of the requirements of plants and that some plants are desirable in the garden and some are not.

\section{Family Time}

\section{Figure 3. Family time}

Please draw your experience from the community gardens. You can include, plants, animals, people and anything else you want.

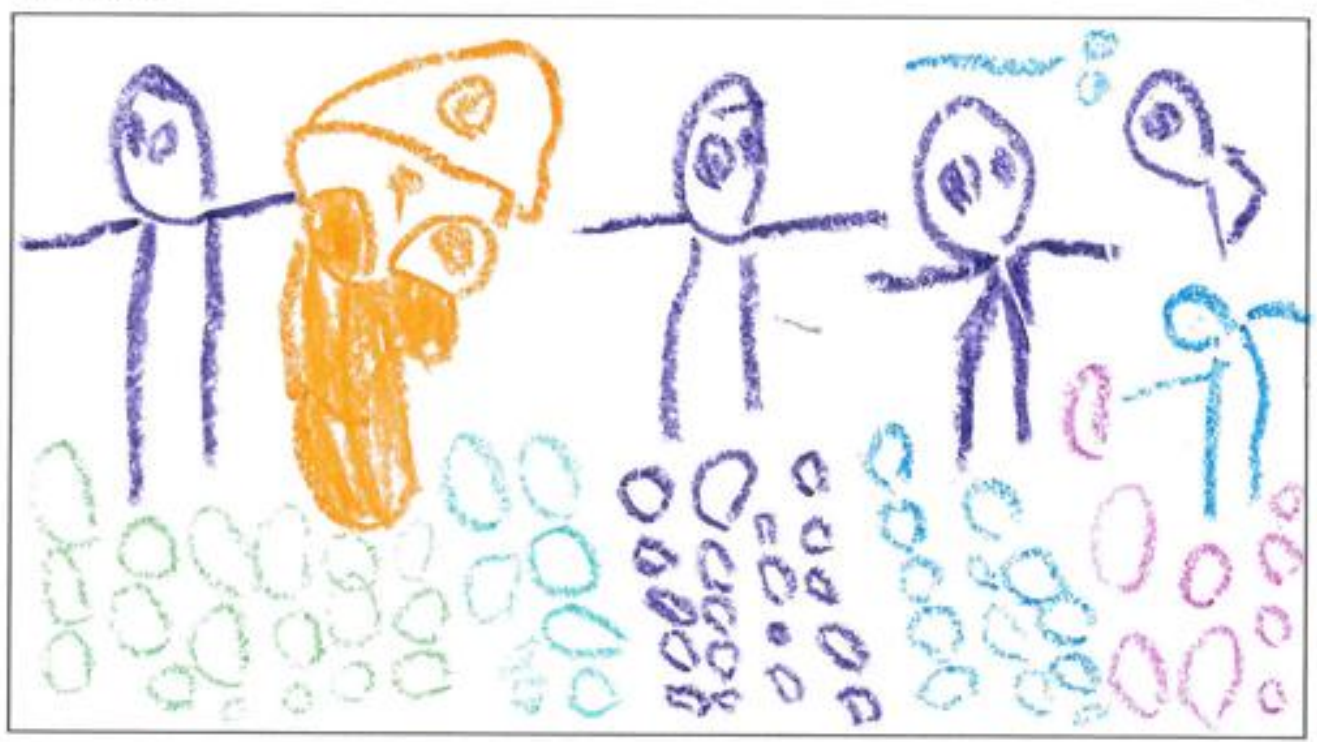

Figure 3 presents a 4-year-old boy's representation of his family time at the community garden. In this picture, all the members of his family are represented, and he shows them walking together in the garden on a multi-colored path. His representation shows the garden separated into different sections. He has drawn several different animals that they came across in the garden-a rolly-polly, a snail and a one-eyed ant. He shows his brother interacting with a rolly-polly. His representation of himself, his mother and his father are in one color, while his brother is in a different color. It is interesting that there are no obvious representations of vegetables, only animals. He includes everyone in the family, which could possibly be interpreted as he perceives the community garden to be a family experience rather than an individual experience. 


\section{Family Interviews}

The family interviews sought to identify families' motivations for participating in community gardening, the experiences of parents and children during the educational workshops in the community garden, and any benefits they gained. Excerpts from the interviews, along with their codes and themes, can be seen in Appendix C.

Parents reported a range of motivations for participating in the Hilltop community garden and their educational workshops. First, most parents gave financial reasons for participating. They noted that produce is expensive in grocery stores. However, families were reluctant to invest money into garden infrastructure at their house without being certain that it would be successful. Thus, they sought education about gardening. Some families reported that after gaining the necessary practical skills and knowledge from Hilltop community garden, they would attempt growing vegetables in their home garden.

Second, limited space at their residence was another reason that led families to community gardening. One family had the idea of growing hydroponically at their house because of their limited space. This family pointed out the importance of the education workshops.

Third, socializing played an important role in families' engagement in community gardening. One family mentioned that they were moving away from Bloomington but that finding a new residence near a community garden was of great importance to them not only for food access but for socializing as well.

Finally, knowledge and recreation were also important factors for the families' participation in community gardening. Most of the families identified time spent in the community gardens as both educational and recreational.

In contrast to our hypothesis, none of the participants reported changes in proenvironmental behaviors during or after the workshops.

Both parents and children had a very positive opinion about the educational workshops held in the Hilltop community garden. During the interviews, participants often illustrated positive impacts with events that took place while gardening. All families mentioned that they learned a lot from the instructors themselves, and some families identified an associated knowledge development in their children. Another positive impact that parents reported was the fact that their children started eating healthier and increased their vegetable intake.

In conjunction with their drawings, children were encouraged during the interviews to talk about their special memories from the community garden. The majority of the special memories reported included animals rather than plants. The animals were a resident cat of the community garden, birds, insects, moles and bunnies.

Two families made comments for improving the education program. Three families commented that their children did not participate in the classroom activities but 
enjoyed the outdoor work. All families identified that this is a family program and acknowledged the limitations that instructors had working with both adults and children.

\section{Discussion}

The aim of this study was to investigate the impact of community gardens' educational workshops as an intervention to foster sustainable lifestyles among family members. The majority of the participants did not have any gardening experience preceding the intervention. Our initial hypothesis was that after the educational workshops, families would report more pro-environmental behavior.

Families identified specific knowledge gained while participating in the community garden, e.g. knowledge of pollinators. Although our quantitative data analysis could not determine causality, the data indicates that these changes were because of the educational workshops provided in the community garden.

Our findings through the ethogram on the significant positive correlation between parents' and children' behavior is supported by other research suggesting that children follow their parents' behavior when it comes to sustainability (Grønhøj \& Thøgersen, 2009).

We also found a significant positive correlation between environmental behavior and engagement in gardening. This could be interpreted to mean that the more one works in nature, the more pro-environmental behavior one is likely to have and develop. As discussed above, there was no reported evidence of increased proenvironmental behaviors attributed to the workshops. Although participants increased their knowledge, they did not necessary act more sustainably, which could be a future implication for such workshops. Investing more in developing experiences and emotions as a mode to raise pro-environmental behaviors has been discussed in other studies as well. The lack of correlation between environmental knowledge and behavior and the need to use emotions to develop pro-environmental behavior has been discussed in multiple studies, such as those by Carmi, Arnon, and Orion (2015), and Pooley and O'Connor (2000).

None of the interviewed families reported that their environmental orientation had changed through participation in the community garden or the educational program. Some of the interviewees discussed some environmental challenges that were brought to their attention during the workshops, but they did not report undertaking any actions to mitigate these challenges. The codes from our interviews suggest that families received and perceived the direct benefits from engaging in community gardening such as increased socializing, knowledge expansion, monetary benefits and family time through recreation, but participants did not make the connection with environmental behaviors and sustainability. We suggest that in order to establish that connection, educational workshops should have a more specific and constant orientation toward sustainability rather than just gardening practices. 
Studying and observing how families engage together in community gardens, we can concur on the importance of families as a social unit. From a practitioners' perspective, it is important to structure future family education workshops in ways that enable both parents and children to make the most of them, despite their age differences.

Nonetheless, several families participated in the educational workshops as an introduction to gardening and vegetable growing. This introduction was very important to them, as they could later transfer these skills to their home vegetable garden. This transfer of skills signifies the importance of gardening-related education in community gardens. If families have their own home vegetable gardens, then the need for vehicle use to acquire food can be minimized. It is thus possible that community gardens could act as a stepping-stone to more residentialbased food production (when lack of gardening space is not an issue), thereby leading to more sustainable cities.

\section{Limitations}

There are limitations to our study and our analysis. Hilltop community garden may not represent the typical community garden setting in the U.S. as they offer structured educational programs while the majority of community gardens do not. Further, our participants were only from one community garden.

Finally, due to the fact that the ethogram was developed by a single researcher, it was not possible to run an inter-rater reliability test, and such a test would have strengthened the reliability of the instrument used in this study.

\section{Future Research}

Despite the limitations in our study, we believe that the methodologies presented are a great tool for future studies, allowing researchers an in-depth understanding of participants' behaviors. In her paper, Hsu (2014) suggested that interviews should be incorporated with drawings in future studies to allow researchers a more holistic understanding of participants' drawings. Our study has exhibited this importance and the results of having interviews with children to discuss their experiences with the aid of their drawing.

Future research in community gardens and family sustainability should focus on larger participant sample sizes and should compare findings from community gardens that offer structured educational workshops to community gardens that do not offer educational workshops.

\section{Conclusion}

The findings of our study indicate that families engaging in community gardening can promote city sustainability in two ways. One way is by developing the skills and knowledge needed for growing vegetables and directly growing food in the garden, and the second way is by families transferring these skills and knowledge to their home gardens and incorporating vegetable gardening in their everyday life. The interview findings suggest that families have experienced several different direct benefits from engaging in community gardening, and thus they would continue engaging in this activity. Although families' reasons for participating in community 
gardening was not directly due to environmental concerns, rather due to the direct benefits they receive such as socializing, health benefits and financial motives, the families are still making a contribution to city sustainability by participating in community gardening through practices such as organic farming and on-site compost production. Among the 13 families that participated in the Hilltop program, two of them traveled regularly to and from the community gardens on their bicycles, while the other 11 used their personal cars. Creating a network of community gardens that are easily accessible on foot, by bike or with public transportation could create more sustainable cities. Another important finding from our study was that the educational workshops provided a platform for the families to learn together and engage in activities that resulted in spending "quality time, a valuable outcome (McDonald \& Maurer, 2015; Freeman \& Zabriskie, 2002).

Konstantinos Stavrianakis is a Ph.D. student in Leisure Behavior at the School of Public Health at Indiana University, Bloomington. He specializes in research into how environmental education influences environmental behavior in urban settings. Kostas has extensive experience as an environmental education practitioner as well as an academic background in Ecology and Environmental Science.

James Farmer, Ph.D., is an assistant professor in the School of Public HealthBloomington at Indiana University. His research is focused on sustainable behavior and decision-making within the realms of community food systems and natural resources. Dr. Farmer teaches in the Outdoor Recreation, Parks, and Human Ecology program, co-directs the IU Campus Farm, and convenes the Human Dimensions Research Lab at Indiana University.

\section{References}

Algert, S. J., Baameur, A., \& Renvall, M. J. (2014). Vegetable output and cost savings of community gardens in San Jose, California. Journal of the Academy of Nutrition and Dietetics, 114(7), 1072-1076.

Armstrong, D. (2000). A survey of community gardens in upstate New York: Implications for health promotion and community development. Health Place, $6(4), 319-327$. Retrieved from https://www.ncbi.nlm.nih.gov/pubmed/11027957.

Barosh, L., Friel, S., Engelhardt, K., \& Chan, L. (2014). The cost of a healthy and sustainable diet-who can afford it? Australian and New Zealand Journal of Public Health, 38(1), 7-12.

Bernard, H. R. (2006). Research methods in anthropology: Qualitative and quantitative approaches. (4th ed.). Lanham, MD: Sage Publications.

Broome, T. (2015). Food Waste Reduction. Retrieved from https://fifthseasongardening.com/food-waste-reduction 
Carmi, N., Arnon, S., \& Orion, N. (2015). Transforming environmental knowledge into behavior: The mediating role of environmental emotions. The Journal of Environmental Education, 46(3), 183-201.

Carney, P. A., Hamada, J. L., Rdesinski, R., Sprager, L., Nichols, K. R., Liu, B. Y., . . . Shannon, J. (2012). Impact of a community gardening project on vegetable intake, food security and family relationships: A community-based participatory research study. Journal of Community Health, 37(4), 874-881. Retrieved from https://www.ncbi.nlm.nih.gov/pubmed/22194063.

Castro, D. C., Samuels, M., \& Harman, A. E. (2013). Growing healthy kids: A community garden-based obesity prevention program. American Journal of Preventive Medicine, 44(3), S193-S199.

Corkery, L. (2015). Community gardens as a platform for education for sustainability. Australian Journal of Environmental Education, 20(1), 69-75. doi: $10.1017 /$ s0814062600002317

Creswell, J. W. (2013). Qualitative inquiry and research design: Choosing among five approaches (3rd ed.). London: Sage.

Creswell, J. W. \& Plano-Clark, V. L. (2007). Desiging and conducting: Mixedmethods research. Los Angeles, CA: Sage.

Damerell, P., Howe, C., \& Milner-Gulland, E. J. (2013). Child-orientated environmental education influences adult knowledge and household behaviour. Environmental Research Letters, 8(1), 015016. doi:Artn 01501610.1088/1748-9326/8/1/015016

Ferris, J., Norman, C., \& Sempik, J. (2001). People, land and sustainability: Community gardens and the social dimension of sustainable development. Social Policy \& Administration, 35(5), 559-568. doi:10.1111/1467-9515.t011-00253

Grønhøj, A., \& Thøgersen, J. (2009). Like father, like son? Intergenerational transmission of values, attitudes, and behaviours in the environmental domain. Journal of Environmental Psychology, 29(4), 414-421.

doi: 10.1016/j.jenvp.2009.05.002

Guitart, D., Pickering, C., \& Byrne, J. (2012). Past results and future directions in urban community gardens research. Urban Forestry \& Urban Greening, 11(4), 364-373. doi:10.1016/j.ufug.2012.06.007

Günindi, Y. (2017). Preschool children's perceptions of the value of affection as seen in their drawings. International Electronic Journal of Elementary Education, 7(3), 371-382. 
Hendrickson, D., Smith, C., \& Eikenberry, N. (2006). Fruit and vegetable access in four low-income food deserts communities in Minnesota. Agriculture and Human Values, 23(3), 371-383.

Hsu, Y.-H. (2014). Analyzing children's drawings. Paper presented at the 21st Century Academic Forum Conference, Univeristy of California Berkeley.

Kollmuss, A., \& Agyeman, J. (2002). Mind the gap: Why do people act environmentally and what are the barriers to pro-environmental behavior? Environmental Education Research, 8(3), 239-260.

Krasny, M. E., \& Tidball, K. G. (2009). Community gardens as contexts for science, stewardship, and civic action learning. Cities and the Environment, 2(1), 118.

Kuhlman, T. \& Farrington, J. (2010). What is sustainability? Sustainability, 2(11), 3436-3448. https://doi.org/10.3390/su2113436

Lauricella, A. R., Wartella, E., \& Rideout, V. J. (2015). Young children's screen time: The complex role of parent and child factors. Journal of Applied Developmental Psychology, 36, 11-17. doi:10.1016/j.appdev.2014.12.001

Lawson, L. J. (2005). A century of community gardening in America. Berkeley and Los Angeles, California and London, England: University of California Press.

Macdiarmid, J. I. (2013). Is a healthy diet an environmentally sustainable diet? Proceedings of the Nutrition Society, 72(1), 13-20.

MacDonald, S., \& Maurer, M. (2015). Families learning together. Science and Children, 52(9), 44-49.

Meeusen, C. (2014). The intergenerational transmission of environmental concern: The influence of parents and communication patterns within the family. Journal of Environmental Education, 45(2), 77-90. doi: $10.1080 / 00958964.2013 .846290$

Middle, I., Dzidic, P., Buckley, A., Bennett, D., Tye, M., \& Jones, R. (2014). Integrating community gardens into public parks: An innovative approach for providing ecosystem services in urban areas. Urban Forestry \& Urban Greening, 13(4), 638-645. doi:10.1016/j.ufug.2014.09.001

Nippert-Eng, C. (2015). Watching closely: A guide to ethnographic observation. New York: Oxford University Press.

Okvat, H. A., \& Zautra, A. J. (2011). Community gardening: A parsimonious path to individual, community, and environmental resilience. American Journal of Community Psychology, 47(3-4), 374-387. doi:10.1007/s10464-010-9404-z 
Patterson, G. R. (1975). Families: Applications of social learning to family life. Champaign, IL: Research Press.

Pooley, J. A., \& O'Connor, M. (2000). Environmental education and attitudes:

Emotions and beliefs are what is needed. Environment and Behavior, 32(5), 711-723. doi: $10.1177 / 0013916500325007$

Robinson, J. M., \& Farmer, J. R. (2017). Selling local: Why local food movements matter. Bloomington, IN: Indiana University Press.

Stake, R. E. (1995). The art of case study research. Thousand Oaks, CA: Sage.

Stake, R. E. (2005). Qualitative case studies. In N. K. Denzin \& Y. S. Lincoln (Eds.), The Sage handbook of qualitative research (pp. 443-466). Thousand Oaks, CA: Sage Publications Ltd.

Tracy, S. J. (2012). Qualitative research methods: Collecting evidence, crafting analysis, communicating impact. Malden, MA: John Wiley \& Sons.

Turner, B. (2011). Embodied connections: Sustainability, food systems and community gardens. Local Environment, 16(6), 509-522.

doi: $10.1080 / 13549839.2011 .569537$

Turner, B., Henryks, J., \& Pearson, D. (2011). Community gardens: Sustainability, health and inclusion in the city. Local Environment, 16(6), 489-492.

doi:10.1080/13549839.2011.595901

Veen, E. J., Bock, B. B., Van den Berg, W., Visser, A. J., \& Wiskerke, J. S. C. (2015). Community gardening and social cohesion: Different designs, different motivations. Local Environment, 21(10), 1271-1287.

doi:10.1080/13549839.2015.1101433

Walter, P. (2013). Theorising community gardens as pedagogical sites in the food movement. Environmental education research, 19(4), 521-539. doi: $10.1080 / 13504622.2012 .709824$

Williams, D., \& Brown, J. (2013). Learning gardens and sustainability education: Bringing life to schools and schools to life. New York: Routledge.

Yuen, F. C. (2004). "It was fun... I liked drawing my thoughts": Using drawings as a part of the focus group process with children. Journal of Leisure Research, $36(4), 461-482$.

Zick, C. D., Smith, K. R., Kowaleski-Jones, L., Uno, C., \& Merrill, B. J. (2013). Harvesting more than vegetables: The potential weight control benefits of community gardening. American Journal of Public Health, 103(6), 11101115. doi:10.2105/Ajph.2012.301009 


\section{Appendix A. Example Ethogram}

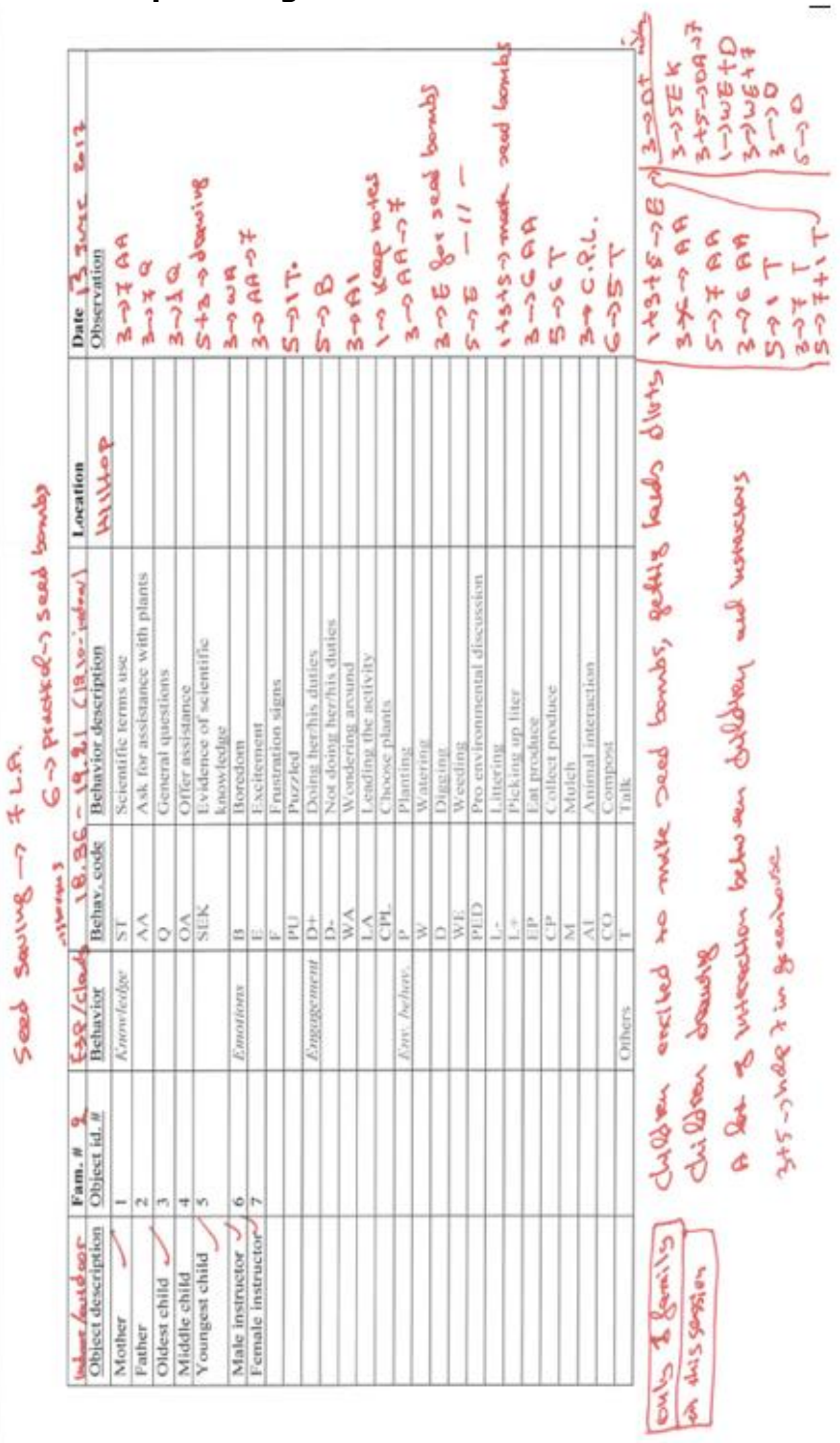




\section{Appendix B. Codebook for the Ethogram}

\begin{tabular}{|c|c|}
\hline Behavior code & \\
\hline \multicolumn{2}{|c|}{ Environmental knowledge } \\
\hline ST & Use of scientific terminology, including photosynthesis, compost, etc \\
\hline AA & Ask questions about plants. Includes the longevity of plants, how to harvest, where to buy plants from \\
\hline Q & Questions not related to $\mathrm{AA}$ \\
\hline OA & Offer assisstance \\
\hline SEK & Evidence of scientific knowledge, that varies between ages. Include the id of animals, plants, the colour of vegetables etc. Differs for different ages \\
\hline \multicolumn{2}{|r|}{$e_{1}$} \\
\hline B & Boredom, signs that the participant is not attracted to the activity, not engaging in the activity \\
\hline E & Excitement, signs that the participant is excited about the activity \\
\hline F & Frustration, cry, shouting \\
\hline PU & Puzzled \\
\hline \multicolumn{2}{|l|}{ Engagement } \\
\hline$D+$ & Doing their duties, evidences of undertaking their duties, watering, litter picking, gloves, tools, gate duty \\
\hline D. & Not doing their duties, no evidence undertaking their duties, watering, litter picking, gloves, tools, gate duty \\
\hline WA & Wandering around, participants distracted by something else and walk around \\
\hline LA & Leading the activity, telling the others what to do and lead by example \\
\hline CPL & Choose plants to be planted \\
\hline \multicolumn{2}{|c|}{ Environmental behavior } \\
\hline p & Planting and replanting \\
\hline W & Watering the plants, filling up the water container and water plants \\
\hline D & Digging \\
\hline WE & Weeding \\
\hline PED & Pro environmental discussion, any discussion that lead to discussing environmental benefits \\
\hline L: & Littering \\
\hline L+ & Picking up litter \\
\hline EP & Eating produce, from their plot or from the communal area, strawberries \\
\hline$C P$ & Collect produce, harvest their produce from their plot or the communal area, strawberries \\
\hline M & Mulching, bring mulch with wheel barrow and apply in the plot \\
\hline Al & Animal interaction, including the resident cat, worms, insects, etc \\
\hline $\mathrm{CO}$ & Compost, take their weeds to the compost area \\
\hline T & Talking, talking between subjects that is not related to the community gardening \\
\hline
\end{tabular}




\section{Appendix C. Examples of Interview Quotes with Themes}

\begin{tabular}{|c|c|c|}
\hline Interview Quotes & Codes & Themes \\
\hline $\begin{array}{l}\text { Mother: "I wish I could think of specific examples, but } \\
\text { I hear the, say things that they have learned or pick } \\
\text { up bugs that they have seen here in the gardens and } \\
\text { they know things about them, they know things that I } \\
\text { am sure they have learned here..." } \\
\text { Father: "I have heard them talking outside of this } \\
\text { context, like about, pollinating and stuff like that and } \\
\text { it is on their mind in a way that it was not } \\
\text { before...they see insects coming from flower to flower } \\
\text { and talk about pollinating them." }\end{array}$ & $\begin{array}{l}\text { Talking, learned, } \\
\text { know, pollinating }\end{array}$ & $\begin{array}{l}\text { - Knowledge } \\
\text { - Transferring } \\
\text { skills }\end{array}$ \\
\hline $\begin{array}{l}\text { Mother: One thing I was hoping for, is to get more } \\
\text { vegetables in our garden and in our diet...and we } \\
\text { were walking through Bloomingfood (local food } \\
\text { retailer with organic produce) just this week and Tina } \\
\text { (daughter) said now that we have our garden I am } \\
\text { interested in eating vegetables...yeah! but that was } \\
\text { something that I hoped would happen." }\end{array}$ & $\begin{array}{l}\text { Interested in eating } \\
\text { vegetables, diet, } \\
\text { more vegetables }\end{array}$ & $\begin{array}{l}\text { - Knowledge } \\
\text { - Transferring } \\
\text { skills }\end{array}$ \\
\hline $\begin{array}{l}\text { Father: "too expensive... we buy organic, so we figure } \\
\text { if we buy, we might just grow it ourselves." } \\
\text { Oldest child: "that way we do not spend so much } \\
\text { money" }\end{array}$ & $\begin{array}{l}\text { Expensive, not } \\
\text { spend so much } \\
\text { money }\end{array}$ & $\begin{array}{c}\text { - Financial } \\
\text { motives }\end{array}$ \\
\hline $\begin{array}{l}\text { Mother: "I told George (husband) that I was } \\
\text { debating on whether it would be worth build a plot at } \\
\text { our house, but I did not want to invest in building a } \\
\text { raised bed and doing all of it and I thought that this is } \\
\text { a perfect opportunity to not only educating them } \\
\text { (children) but also try it out without investing a lot in } \\
\text { our home." }\end{array}$ & $\begin{array}{l}\text { Investing, } \\
\text { educating, build, } \\
\text { perfect opportunity }\end{array}$ & $\begin{array}{l}\text { - Knowledge, } \\
\text { financial } \\
\text { - Motives } \\
\text { - Transferring } \\
\text { skills }\end{array}$ \\
\hline $\begin{array}{l}\text { Father: "We are limited living in an apartment, we } \\
\text { can't grow vegetables, so this provides an } \\
\text { opportunity to grow vegetables" }\end{array}$ & $\begin{array}{l}\text { Limited living in } \\
\text { apartment }\end{array}$ & $\begin{array}{l}\text { - Financial } \\
\text { motives }\end{array}$ \\
\hline $\begin{array}{l}\text { Researcher: Ok, so, after the community gardens } \\
\text { here in Hilltop, do you think you will try again and do } \\
\text { it in your house? } \\
\text { Father: "Yes, during the program actually we tried } \\
\text { to create our own hydroponics in our house...it did not } \\
\text { work with mint, but it did work with peppers. We } \\
\text { want to expand that and try different things. } \\
\text { Hydroponics inside the house." } \\
\text { Researcher: "Do you think what you were taught in } \\
\text { Hilltop helped you?" } \\
\text { Father: "Yes, it was very helpful." } \\
\text { Researcher: "Although you did not do hydroponics? } \\
\text { Father: "Yes. It needs specific treatments, but in } \\
\text { general, they will be the same. Probably we need } \\
\text { more...the food for hydroponics is different but in }\end{array}$ & Tried, helpful & $\begin{array}{l}\text { - Knowledge } \\
\text { - Transferring } \\
\text { skills }\end{array}$ \\
\hline
\end{tabular}




\begin{tabular}{|c|c|c|}
\hline $\begin{array}{l}\text { general it will be the same way we treat normal } \\
\text { plants we treat hydroponics." }\end{array}$ & & \\
\hline $\begin{array}{l}\text { Father: "I would like to say...stepping back one } \\
\text { question, I was surprised how much a community it } \\
\text { feels like, I am not that talkative person with other } \\
\text { families, but I noticed how Joyce (daughter) started } \\
\text { talking with other kids and then occasionally Dona } \\
\text { (wife) would get in a conversation and so, I like that, } \\
\text { it was like having another community to be part of. I } \\
\text { think if I lived in Bloomington, I would still come to } \\
\text { the community gardens here and have still have my } \\
\text { own garden somewhere else." }\end{array}$ & $\begin{array}{l}\text { Surprised, } \\
\text { community, talking, } \\
\text { conversation, own } \\
\text { garden somewhere } \\
\text { else }\end{array}$ & $\begin{array}{l}\text { - Socialization } \\
\text { - Transferring } \\
\text { skills }\end{array}$ \\
\hline $\begin{array}{l}\text { Mother: "Well, it is really important to me that they } \\
\text { (children) have a good understanding of the where } \\
\text { the food comes from, and I wanted them to not only } \\
\text { know the vegetables we grow from the ground but } \\
\text { that we can produce the food we eat. But also, I } \\
\text { wanted them to have that hands-on inquiry } \\
\text { experience of growing food." }\end{array}$ & $\begin{array}{l}\text { Good } \\
\text { understanding, } \\
\text { vegetables grow, } \\
\text { produce food, } \\
\text { inquiry, experience }\end{array}$ & - Knowledge \\
\hline $\begin{array}{l}\text { Researcher: "And would you consider that as a } \\
\text { recreation time? With the family"? } \\
\text { Mother: "Yeah" } \\
\text { Father: "Mostly recreation" } \\
\text { Mother: "Also education" } \\
\text { Researcher: "So, you can combine education with } \\
\text { recreation?" } \\
\text { Mother: "Yes, but I think it is also a quality family } \\
\text { time, so it is something we can do the three of us } \\
\text { together" }\end{array}$ & $\begin{array}{l}\text { Mostly recreation, } \\
\text { education, quality } \\
\text { family time }\end{array}$ & $\begin{array}{l}\text { - Recreation } \\
\text { - Knowledge }\end{array}$ \\
\hline
\end{tabular}

